\title{
Commuting with on-site accommodation in the mining industry and its effects on spatial structures
}

\author{
MARKKU TYKKYLÄINEN
}

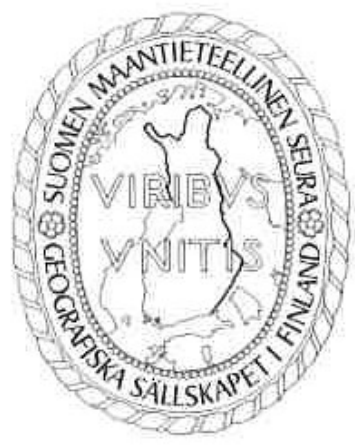

Tykkyläinen, Markku (1996). Commuting with on-site accommodation in the mining industry and its effects on spatial structures. Femia 174: 2, pp. 223-243. Helsinki. ISSN 0015-0010.

An analysis is made of experiences and spatial effects of commuting by air with on-site accommodation for the purposes of resource extraction in sparsely populated areas. The case concerned is that of the Forrestania Nickel Mines in Western Australia, owned by the Outokumpu Group and opened in January 1993. Comparison is made with the Zaldivar Mine in Chile.

This case study demonstrates that the reasons for the growth of airborne long-distance commuting lie in the increasing technical and economic possibilities for organising commuting between urban agglomerations and remote working sites, the introduction of compressed and rotational work schedules and the lifestyle and behaviour of the employees themselves, all of which factors favour long-distance commuting.

Long-distance commuting causes a marked bifurcation in the life of an employee, as his working life and home life are entirely separate. His social ties and family are rooted in the social networks of his actual domicile, and many employees aspire to live in a metropolitan environment, as the availability of services, lifestyle, environment and social networks to be found there foster an attachment with their domiciles, whereas rural mining localities are not attractive for permanent dwelling and are thus not viable housing options if long-distance commuting is available.

This increasing long-distance commuting restructures urban and rural housing and infrastructures. The spatial structure related to mining becomes fragmented, and it becomes a combination of various resource communities connected to home localities by different modes of commuting operating over unpredictable distances. The paper demonstrates clearly that sophisticated technology, efforts to improve economic efficiency and individual preferences may lead to fundamental changes in the spatial structures of sparsely populated areas.

Markku Tykkyläinen, Department of Geography, University of Joensuu, P.O. Box 111, FIN-80101 JOENSUL, Finland. MS received 21st March, 1996 (revised 9th September, 1996).

\section{Introduction}

Commuting by air between working sites and urban domiciles became frequent in remote mining areas, especially in Australia and Canada, in the 1980s. In this new practice, employees spend a fixed number of days working on-site, followed by a given period at home.

Commuting combined with on-site accommodation, which is most common in off-shore industries worldwide, has been developed and adopted rapidly by the mining sector, where it is known as "commuter mining". It includes commuting by air, bus and car. For clarity, the term "long-distance commuting" is taken here to apply to those employees who commute by air, a practice that has evolved into a regional development strategy in very remote areas and has come to replace permanent mining towns in some countries like Australia.

There is very little theory in existence concerning the current restructuring of remote rural settlements based on advanced industries, nor have long-distance commuting and sophisticated industrial development in the 
resource sectors of the economy of rural areas been studied very much. This case study is concerned with housing and commuting at a medium-sized nickel mine in Western Australia, and it reveals central reasons for the adoption of this commuting model in remote areas. It also elaborates upon the applicability of long-distance commuting, which is a matter of local and regional development linked to questions of housing and commuting. The aim is to analyse the reasons for the adoption of long-distance commuting, how the employees adapt to it and the associated rotational and compressed work schedules, what kind of housing the employees prefer when they have to work in a remote mine, and what will be the probable course of urban and rural development when commuting combined with accommodation on-site is introduced.

If long-distance commuting proves to be very successful, it will have the potential to diffuse over remote parts of the earth, i.e. uninhabited areas and areas with a scattered population. It is also evident that the level of development of the country concerned does not greatly influence the feasibility of this new commuting practice, thus leading to its diffusion into developing countries as well.

\section{Sparsely populated areas and long-distance commuting}

A sparsely populated area is a relative concept, of course, and its appreciation is dependent on the interpretation of each individual. It is more or less subjectively defined by researchers, usually in terms of possessing only a few inhabitants per square kilometre at the maximum (Holmes 1981: 4-7).

As the majority of the earth's surface is sparsely populated (Fig. 1) and has relatively little infrastructure but is of increasing commercial interest, a new cost-saving practice of settlement and commuting specifically designed for such areas is finding a ready market. This development has been boosted by the expansion of industries operating in remote areas.

The industry involved in this case study, the Forrestania Nickel Mines, is located in the sparsely inhabited state of Western Australia, and has developed this commuting innovation in order to avoid the problems of isolation and the short supply of commodities that characteristically afflict small communities. Forrestania is a middle-sized mining operator among more than 40 mines which have organised long-distance commuting by air in Australia (Storey \& Shrimpton 1991), the majority of which are located in Western Australia. The owner of the Forrestania Nickel Mines, the Outokumpu Group, also has a half-share in the Zaldivar mine in the Atacama Desert in Chile, a copper mine that provides on-site accommodation combined with bus transport (Fig. 1).

Historically, long-distance commuting has its roots in the camps of seasonal and occasional workers in remote areas. Forest camps in Scandinavia, camps for newcomers in Australia and temporary accommodation in connection with large infrastructure projects in all countries were the predecessors of recent on-site accommodation. Nowadays attempts are being made to reconcile this mode of existence with ordinary family life, which makes all the difference.

The early adopters of long-distance commuting were mining companies in Canada a few decades ago, and comparable arrangements had been also in use in the former Soviet Union. The use of this strategy by the mining industry in Canada increased rapidly in the 1980s. Twenty-four mines were in operation from 1972 to 1993, and the number of mining operations based on long-distance commuting as a percentage of all new gold, uranium and lead/zinc mines exceeded onethird by the latter half of the 1980s (Storey \& Shrimpton 1994).

Commuting by air in Australia was initiated in the Moomba oil and gas fields of South Australia, which originally commenced production in 1968. By the mid-1980s, 1,300 employees were commuting $800 \mathrm{~km}$ from Adelaide to Moomba (Houghton 1993: 283), and the custom increased in other parts of Australia from the early 1980s onwards, being adopted most frequently in Western Australia.

Long-distance commuting has similarly been embraced in the context of the developing countries. Australian miners from Queensland commuted over 1000 kilometres to several mining operations in Papua New Guinea in the early 1990s, for example (Houghton 1993: 289), and commuting by bus associated with on-site accommodation is frequently used in the region of Antofagasta in Northern Chile. Mines such as Zaldivar and La Escon- 


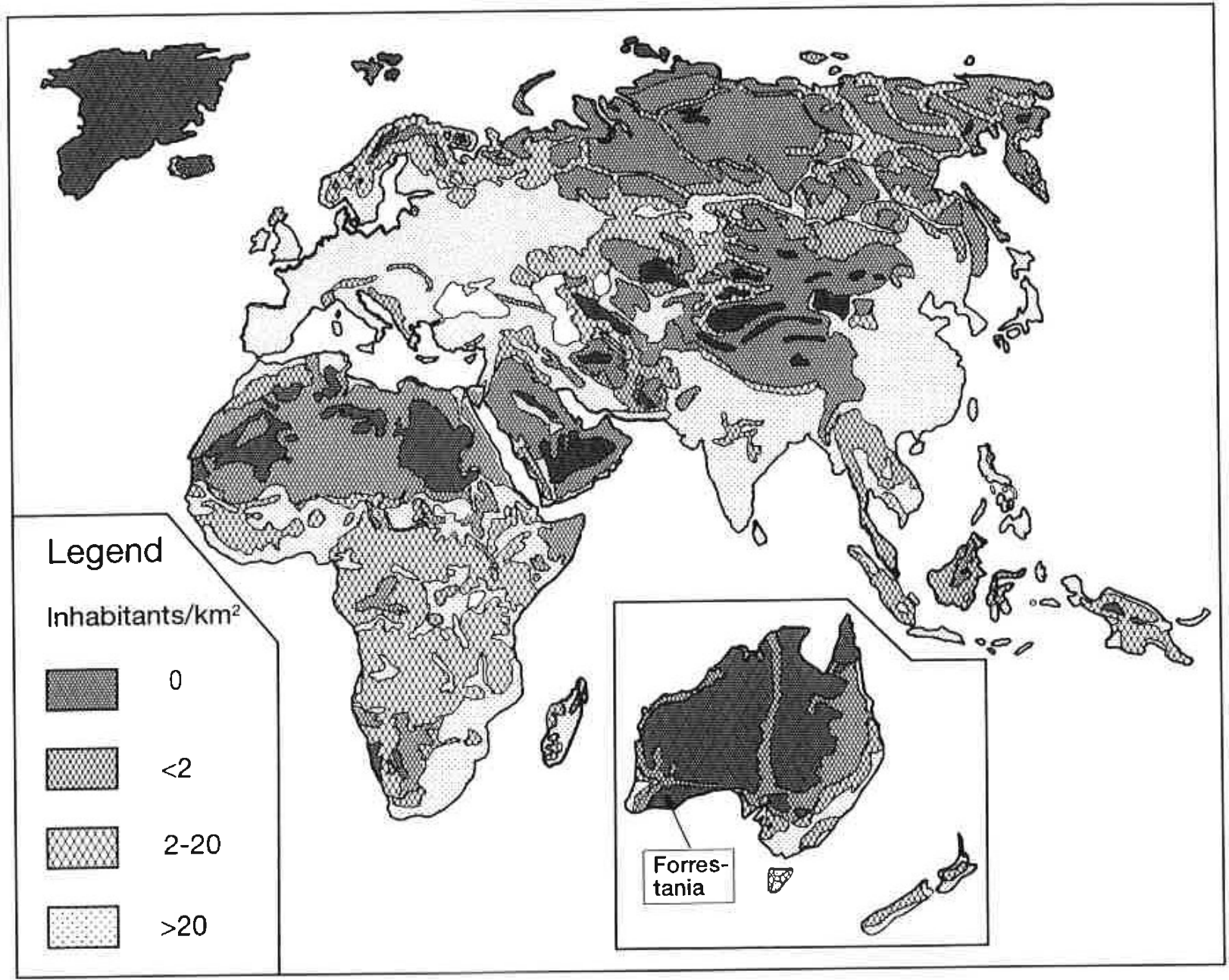

Fig. 1. Distribution of sparsely populated areas (population density less than 2 inhabitants per square kilometre), and the locations of the mines discussed in the text.

dida were operating in this way in 1995 , for instance.

\section{Theoretical considerations: economic networking and communities}

The globalisation of business is becoming an inevitable stage in recent economic development (Luostarinen 1994). Transactions on a global scale induce flows of commodities, people and capital across borders, so that international traffic is increasing more rapidly than intranational traffic (Brotchie 1991), and world trade is expanding more rapidly than the global GDP. National economies are becoming more integrated and are complement- ing each other, especially since many companies have their roots, owners and business interests in many countries and are in effect transnational. Globalisation of this kind has taken place in mining and metal production (Humphreys 1995).

Companies aiming to operate on the global market are the prime initiators of the expansion in economic networking across borders. Industries are increasingly being based on a worldwide organisation of production, and in this way regions and countries are coming to complement each other within the global division of labour. This expansion in production is creating new spatial structures such as industrial areas, transportation and communication links and housing (Dicken 1990: 49). In the mining sector, for instance, transnational vertical integration is creating units 


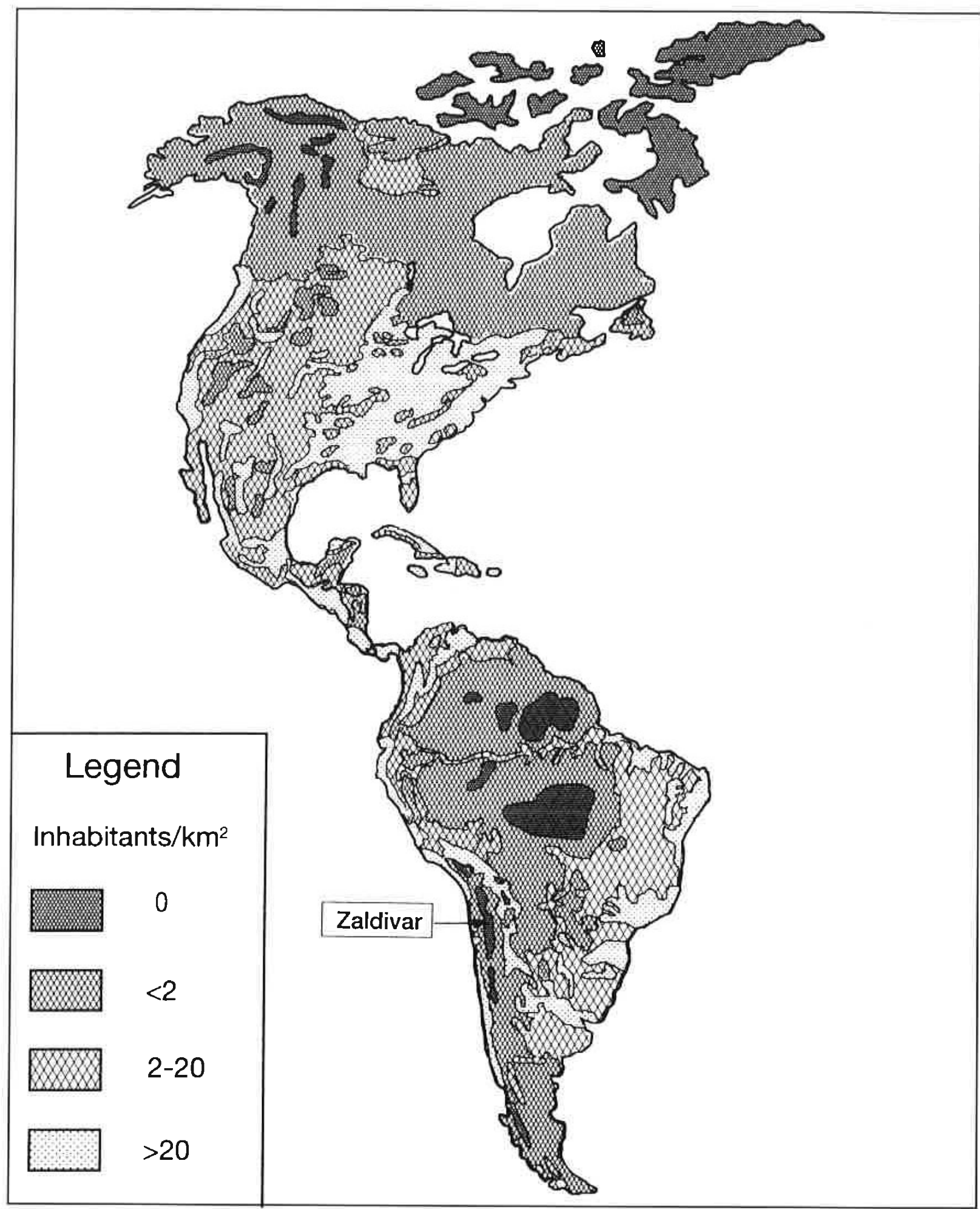

linked across national boundaries in various production chains. Mines are located where the ores exist, but international transportation and communication links connect them efficiently to the processing units in the pro- duction chain of a transnational company. This international networking modifies urban and rural fabrics, and thus the global networks of business can influence the spatial structures of a region and country. 
Economic transactions between the factories of transnational companies are based on point-to-point contacts between numerous dispersed locations, thereby increasing the network character of the spatial structure (Batten 1993). The growth and decline of communities may be viewed as intimately associated with the role acquired by each community in both the national economy and the global context, and these communities are increasingly coming to vary in shape and structure, as this case study will show. As these globalisation tendencies develop further, the socioeconomic development of a locality and region becomes determined by international competition more than ever before. Although global business strategies are often attached to hightech industries such as electronics, for instance, parallel developments are taking place in many other sectors, e.g. mining. Advanced production technologies are being applied in outlying tracts and also in developing countries. These high-tech installations can hardly be operated by employees without housing and commuting arrangements that function at the corresponding level.

The end of the construction of mining towns at remote sites in Australia in the 1970s has marked a considerable revision of regional policy, which affects housing, infrastructural development and the local economies. In this new concept, the construction of mining townships in remote areas has been replaced by long-distance commuting in conjunction with accommodation provided at the working site. This new settlement type was discussed by Newton and Robinson (1987) as an already functioning option among a range of new, more flexible settlement types outlined in order to avoid the problems experienced in single-industry communities.

The fact that the spatial structure of settlements is becoming more versatile in many regions can be interpreted as indicating that the traditional patterns of central places and hinterlands are being replaced by a new spatial organisation as advanced worldwide technologies and new economic activities emerge (Persson \& Wiberg 1995: 4). The spheres of influence of industrial and cultural activities take on highly dissimilar shapes as industries and companies reach out into different parts of the world and different segments of the market. Companies are increasingly operating as networks rather than on a simple territorial basis (Conti 1993), and increasing mo- bility of labour and the new nature of work communities are consequences of their globalising business strategies and new spatial organisation. The Outokumpu Group, for instance, has mines, metal works and subsidiaries in thirty countries, and hence some employees are very mobile, and usually there are no reasons for restricting the recruitment of employees to any specific geographical region.

Taking the Outokumpu Group as an example, the recruitment of the key persons for a resource project is international, but is in the first instance internal to given business areas and the company group, each key person usually being appointed for a few years at a time. This mobility promotes housing in metropolitan areas, where the provision of services is more suitable for international personnel than in a smaller town. Due to the specialised qualifications needed, ordinary employees are often recruited to these technology-intensive resource projects nationwide or even internationally. Their commitment to a particular locality will be then very limited as already observed on a national scale (Urry 1990: 189), and the traditional system of settlements and central places does not necessary hold good when employees are searching for the best suitable solutions to meet their individual needs.

The adoption of long-distance commuting gives new premises for thinking about what is to be considered "local", due to the fact that an individual is tied closely to two places, a place of work and a place of residence, while the traditional environment of the mining community is disappearing. The geographical space for an employee is no longer uninodal, confined to a single locality, but consists of time-space contacts across the ordinary spatial fields of activity. The notions of space and spatial organisation have expanded radically from those frameworks to which people were accustomed in the industrial societies of past decades (Parkers \& Thrift 1980: 243-278; Freeman \& Perez 1988: 52).

\section{Commuting pattern and accommodation in Forrestania}

The present analysis is based on a sampling survey conducted at the Forrestania Nickel Mines, $380 \mathrm{~km}$ east of Perth. The mines are 


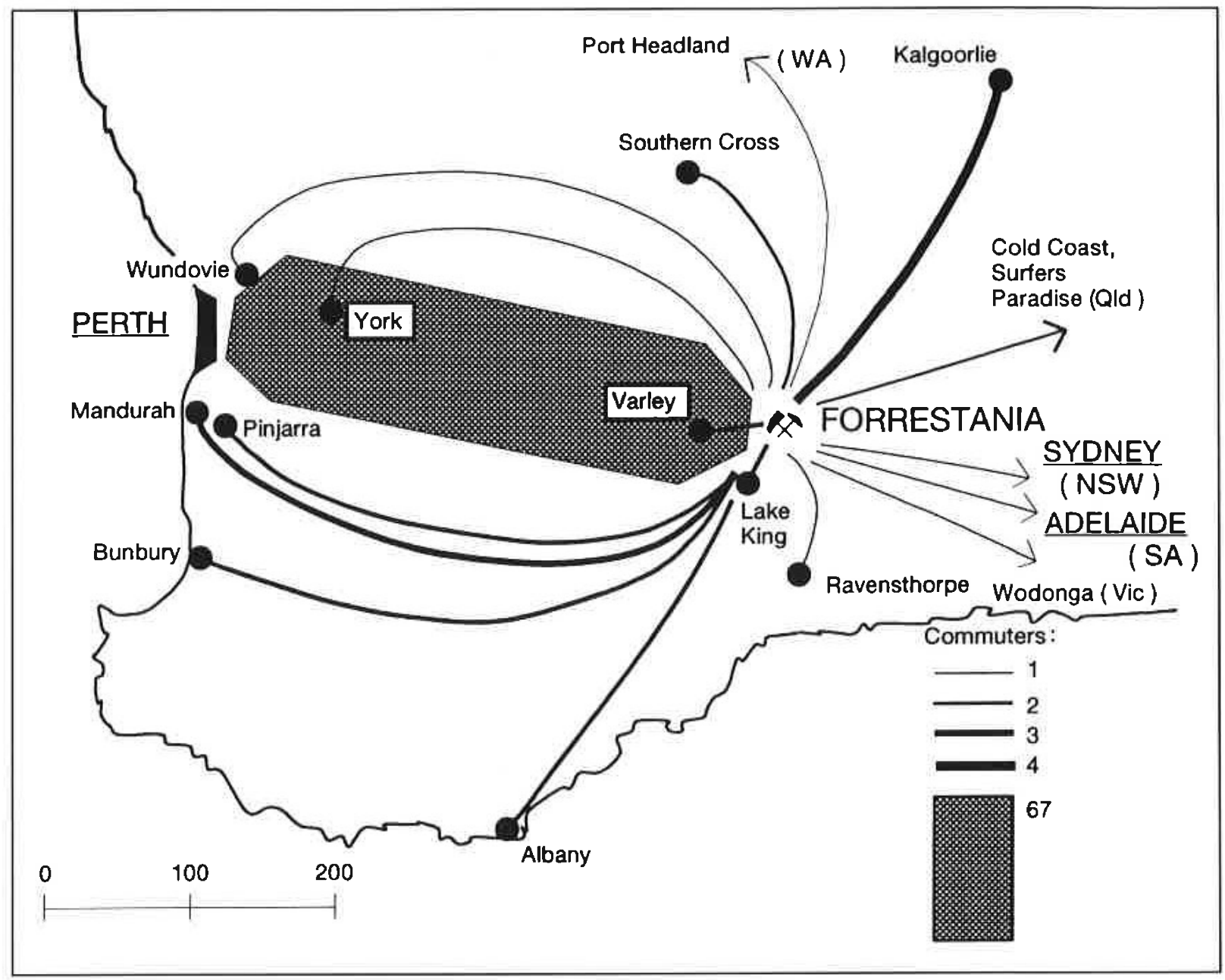

Fig. 2. Commuting pattern of the employees of the Forrestania Nickel Mines in Western Australia. A sample of 102 employees.

located in mallee forest, 10 to $15 \mathrm{~km}$ from a sparsely populated agricultural area. Forrestania is situated in a flat, semi-arid inland area with easy access by car and aircraft. The Nickel Mines, which consist of several mines along a north-south greenstone belt, extract more than 500,000 tonnes of nickel ore per year, which is processed at a highly automated mill in the middle of the mining area and the concentrate transported to the nearest overseas port, Esperance, and from there to the Harjavalta copper and nickel works in Finland. A successful start has been made, for the Forrestania Nickel Mines excavated 600000 tonnes of ore and produced 7500 tonnes of nickel in concentrate in 1994, the respective figures in 1995 being 700000 and 7600 tonnes (Outokumpu 1996a: 14).
The total number of people employed in Forrestania in April 1993 was 193, and they commuted chiefly from Perth and worked mainly in 5 days on $/ 2$ days off or 2 weeks on $/ 1$ week off rotation cycles (Fig. 2). The majority of the employees commuted by air and lived in a well-equipped accommodation complex provided by the mining company which had been completed at the end of 1992, providing board and lodging for 128 employees free of charge. This was enlarged in 1994 to provide accommodation for 225 employees.

The standard of accommodation in the complex can best be compared with that of a wellappointed motel. The original accommodation complex consists of two- to four-room units having a shower and toilet for each 
room, a restaurant, laundry facilities, swimming pool, gym, cable TV and video broadcasting, a bar and a tennis court. The subsequent extension consists of accommodation with shared bathrooms.

At the time of the survey in April 1993, there were also two small contractors' camps at the site. These were temporary units consisting of common social premises supplying food, bedrooms and recreational facilities such as a TV room and a gym. Both contractors were company groups well-known in Australia, and the camps were fitted out in the customary manner. Boral is a diversified company operating over a range of industries from construction to hydrocarbons, and Clough operates in mineral production and development. In 1993, Boral was quarrying in Digger Rocks $18 \mathrm{~km}$ south of the mill site, having established a camp there, and Clough was carrying out tunnelling work from a camp near the Outokumpu accommodation complex.

This work and accommodation practice is comparable to the approach adopted at the Zaldivar mine in the uplands of the Atacama Desert. This is a copper mine owned by the Outokumpu Group and Placer Dome on a fifty-fifty basis, where production started in 1995. The mine produces cathode copper at the site, and production in the first year was 22400 tonnes (Outokumpu 1996a: 13-14). The expected figure in 1996 is 75000 tonnes, and full capacity, 125000 tonnes per year, will be reached in 1997 (Outokumpu 1996b: 3). The mine employs 600 persons on site, and $70 \%$ of the employees live in Antofagasta, $175 \mathrm{~km}$ away. Shifts rotate in 7 days on $/ 7$ days off or $4 / 3$ cycles, and the employees are transported to and from the mine by bus. The standard of board and lodging is similar to that in Forrestania. There is not much difference between the two practices of organising the work, as the main determinants of working life, a compressed work schedule and on-site accommodation, apply on virtually the same principles in both places.

\section{Reasons for long-distance commuting}

\section{Global high-tech mining}

The development of "global high-tech mining" is one of the most important reasons for the growth of long-distance commuting, as it exploits deposits in a project-wise manner, uses labour-saving, advanced technology and operates within global production networks. Commuter mining is suitable for conditions, in which experts are needed occasionally, labour is highly skilled and productive but limited in numbers, and the companies hope to be able to react rapidly to changes in demand and prices. Three aspects of global high-tech mining can be recognized as promoters of commuting and settlement innovations.

Firstly, mining companies have been confronted with considerable reorganisation of their operations during the last few decades. Improved communications and the abolition of trade barriers have promoted global operations in which a competitive mining company consists of a network of mines, mills, plants and R \& D facilities in different parts of the world. The working community is thus a multi-local one, linked together by communications. The basis of operation is not a single mine in one community, but a network of production units using very advanced technology, which creates an atmosphere conducive to more flexible spatial housing solutions.

Secondly, the availability of a wide range of fuel-effective aircraft has improved the feasibility and economy of air transport, at the same time as increased productivity has reduced the number of employees needed in mines, and thus the number to be transported. Automation makes it possible to reduce the direct human labour input on-site, but increases visits by maintenance staff and subcontracting. The employees are thus highly specialised and are recruited state-wide, and even from abroad. The introduction of efficient technology means that the estimated life span of many mines may be relatively short, or uncertain for the market reasons. Work in a mine is more of a project than a life-long career, and expectations regarding housing are hence not directed towards a mining town provided by the company.

Thirdly, new mines have been opened in the southern hemisphere, e.g. in Asia, South America and Australia. Mining expanded especially rapidly in Asia during the 1970s and $1980 \mathrm{~s}$, where the mining and quarrying of four-fifths of the 18 ores listed in the statistics increased (ISY 1988, 1985). South America and Australia follow close behind in terms of growth. Exploration by the transna- 
tional mining companies has broadened out to include Latin America in particular in the 1990s, and governments' diminished concern over minerals development and the privatisation of mining and minerals processing in many countries has opened up opportunities for advanced mining endeavours (Humphreys 1995). There will be more and more mines operating in harsh environments and very remote places in the future, and this will in turn necessitate new commuting and housing practices.

Accompanying the gradual withdrawal of government regulations, and due to the advanced technology and new trends of growth as stated above, mining is forced to be an innovative business searching for new production opportunities in remote areas. All in all, under circumstances in which high-tech mining is spreading, accommodation at the site together with commuting has become an option for employees, constituting an entirely new mode of spatial behaviour.

\section{The workforce and the cost of long-distance commuting}

The traditional mine, with a number of employees often measured in thousands, created a mining community with housing and services supplied by the company. Since then, productivity has increased rapidly, however, so that, for instance, the Forrestania Nickel Mines (the company and its contractors) working at full capacity in August 1994 were employing 227 persons. Technologically advanced mines employ a relatively small number of employees due to the rapid development in mining and process technology, their knowhow for exploiting low-grade ores and the introduction of huge laboursaving machinery. The labour force is highly qualified, but outside experts are occasionally needed. Hence housing needs to be organised for a relatively small number of employees.

The service and construction sector supporting mines is well developed in Australia. Contracting is on the increase and only a specific nucleus of employees work on a permanent basis. Contracting allows the companies to take on experts for a short time and makes the work flexible. Thus $43 \%$ of the employees in mines operating on a long-distance commuting basis in Western Australia in 1991 were employed by contractors (Houghton 1993: 289), as were two-thirds of those working at Forrestania in the start-up phase in 1993. Under conditions in which contract employees require short-term housing, a traditional mining town cannot adequately meet the requirements.

The cost of running a mine based on longdistance commuting and accommodation at the site is considered to be lower than that of a mine with permanent company housing. Wages and salaries are in general higher, but working hours are also longer, up to 2,500 to 2,600 hours per year. In hypothetical cases of mines of 100, 150 and 300 employees, the cost of air transport amounts to about 15 to $23 \%$ of the total labour costs when the mine is located $800 \mathrm{~km}$ from the metropolitan area of Perth in Western Australia (Houghton 1993).

In the case of Forrestania, air transport accounted for an additional cost of $7 \%$ over and above the actual labour costs in April 1993, and likewise in 1994. In effect, the flight from Perth to Forrestania, which is half of the distance assumed in the above-mentioned hypothetical cases, costs the company only half the amount calculated for the hypothetical mines. Naturally, the company is actively looking for the most economical forms of air transport.

Where the operating costs of an accommodation complex, including all aspects of board and lodging, are estimated to increase the labour costs by $17-20 \%$ in the three hypothetical mines, the figure at Forrestania is $12 \%$, i.e. accommodation is provided at low cost. Likewise, the capital write-offs for the accommodation complex, which almost double the cost of board and lodging, mean a total addition to the actual labour costs of $21 \%$, which is well below that for the hypothetical mines. Investments in the accommodation complex at Forrestania were only almost a half of the corresponding estimate for a mine of 100 employees, 5.6 million Australian dollars. This relatively low total cost per employee is due to both better accessibility and cost-efficient management.

In general, investments in temporary accommodation complexes do not represent a substantial part of the investments in a mining project as a whole. In the case of an advanced nickel mine with an on-site mill, the value of the accommodation investment is only a few per cent of the total investment, $3 \%$ in the Forrestania case.

Although the expenses of commuting by aircraft and of accommodation add an 
additional one-fourth to one-third to the company's labour costs, the company saves money because it does not have to invest in a mining town, and it may also benefit from less problematic labour and social relations than in an isolated mining community.

Long-distance commuting has proved to be a viable option in remote areas, and is often the most economic way of organising housing. The relatively low investment costs, competitive price of flights and flexibility in the use of contracting in conjunction with a relatively small number of permanent employees are all factors that make this alternative more profitable than establishing a separate mining town.

Rationalisation continues to confront the mining sector and cause it to develop, and the mines will be increasingly robotised and remote-controlled, leading to a decrease in the number of employees on-site (Pukkila et al. 1994). Thus, technological and economic circumstances favour long-distance commuting now and will do so even more in the future. From these points of view, the diffusion of long-distance commuting is irreversible.

\section{The standard of on-site accommodation and attraction factors perceived by the employees}

One of the key questions in the Forrestania study concerned the satisfaction of the employees themselves with long-distance commuting and accommodation at the mine. The majority of the employees living in the mining company's new accommodation complex were highly satisfied with it, but the two temporary camps arranged by the contractors, Boral and Clough, were criticised because the units were more modest (Fig. 3). The assessment of the accommodation complex and the camps of the contractors clearly indicates that the premises of the accommodation complex were concerned very satisfactory, the main shortcomings being considered with leisuretime activities on the site. A bar, poolroom, indoor gym, tennis, swimming pool and sauna were not among the facilities provided in the camps run by Boral and Clough (Fig. 3).

The mining company aims to provide accommodation and flights at a level that ensures that the turnover of employees is as low as possible and they consider that they have a pleasant environment in which to live in the long run. The employees of the con- tractors were working for a much shorter period, however, most of them only during the investment phase. These two business strategies explain the differences in housing and opinions.

The survey revealed in Forrestania that the employees desired more leisure activities and would have liked improvements to that part of their everyday life. Boredom and the monotony of social life, as also found in permanent mining towns, are difficult to abolish in a remote accommodation complex. On the other hand, when the question was posed, "Why might you plan to leave the mine?", no one referred to the premises or to life in the complex and camps as valid reasons. Thus, the accommodation conditions and the social life at the level at which they were in Forrestania are not crucial factors determining whether employees stay or leave.

It is a very common opinion that employees express general satisfaction with long-distance commuting and do not appear to have any long-term difficulties in adjusting to work schedules which involve lengthy periods in remote mines (Houghton 1993). These favourable attitudes are thought to exist for two main reasons. Firstly, companies provide financial incentives to attract employees to the mines. Secondly, the compressed work schedules associated with long-distance commuting provide employees with extensive periods of leisure in which to pursue recreational activities and to spend more time with their families than do many employees working eight-hour days, five days per week (Houghton 1993). In addition it is assumed, that ideas of being able to improve their spouses' careers and children's education in the metropolitan areas help them to tolerate the loneliness and boredom associated with living in remote localities.

It is obvious that financial incentives are one reason for working in remote mines. When the employees were asked to state reasons for having decided to come and work in Forrestania, savings and pay ranked high on the list (Tykkyläinen 1994: 98). Recently hired employees appreciated the opportunities for new experiences most of all, an aspect which was not ranked high at all by the employees of the contractors. The Outokumpu Group as a responsible mining operator in Australia was a newcomer, which at least partly explains the high value attached to the search for new experiences. 


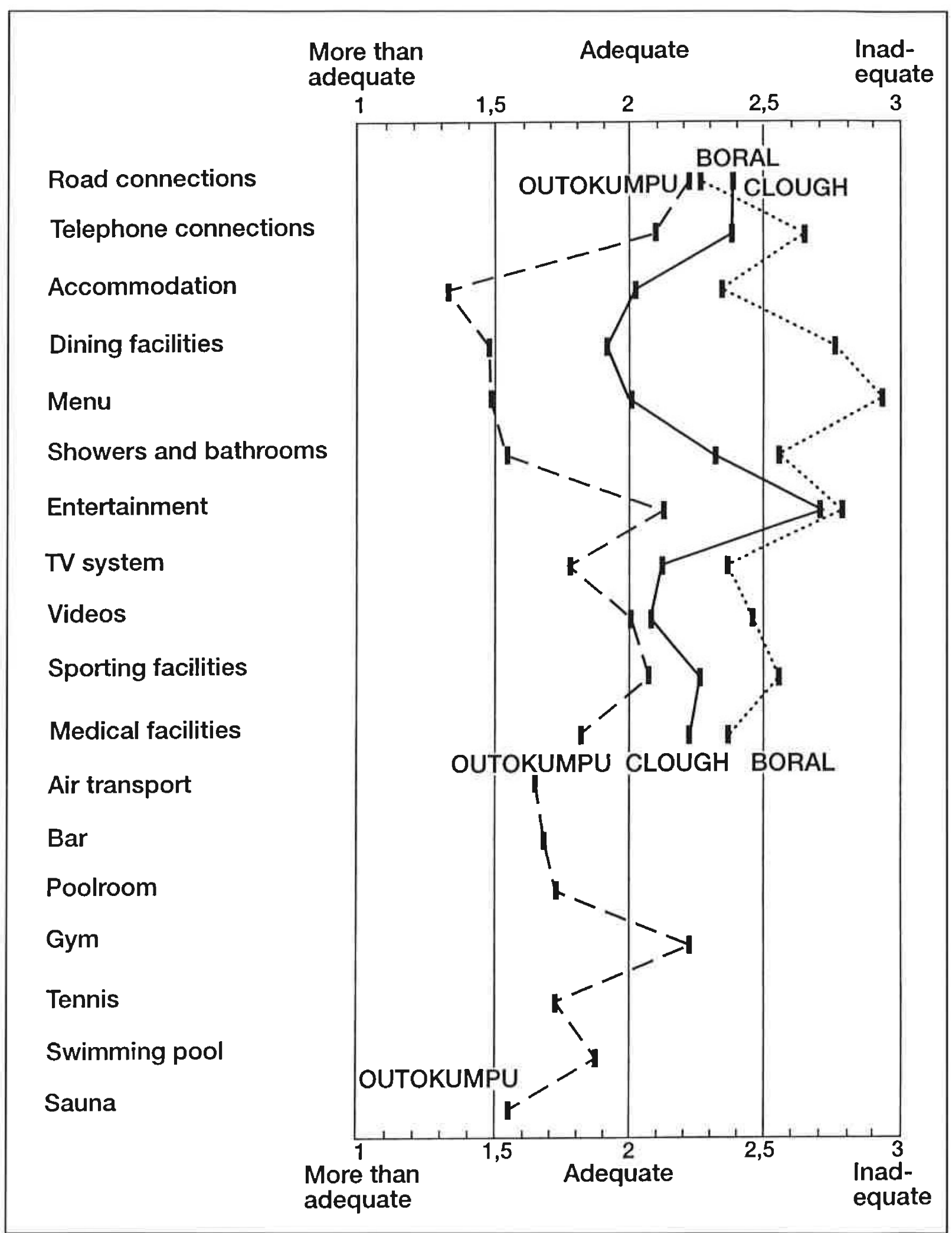

Fig. 3. Standards of on-site accommodation and services provided by the companies. Arithmetical means of the questionnaire answers are presented separately for those respondents housed by Outokumpu (67), Clough (20) and Boral (13). 


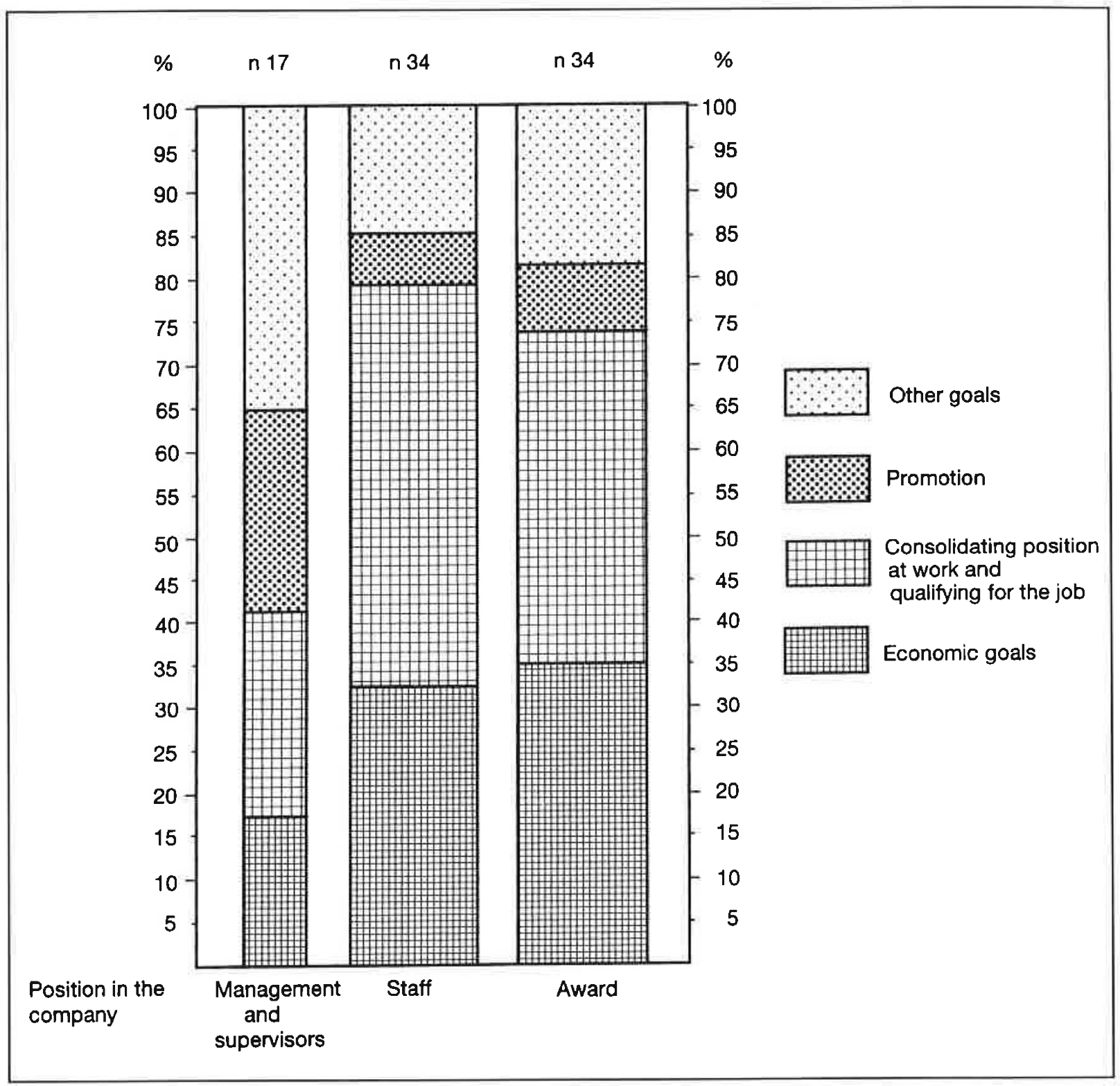

Fig. 4. Nature of the goals that the employees hoped to achieve by working in Forrestania.

A question was put regarding the existence and content of particular goals that the employees hoped to achieve in Forrestania. On average, one-third of the employees who had a definite goal in working at the mine felt that it was economic in nature, often a matter of saving for a certain purpose. In general, the higher the socioeconomic status of the employee, the less important his economic motives were (Fig. 4). The socioeconomic groupings are based on a classification used at the mine, and "award" means the category of operative workers.
Although economic factors such as higher pay served to explain the attractiveness of work in remote mines, they should not be exaggerated, and many employees also assigned very great weight to factors such as the gaining of more experience, the improving of skills and the seeking of promotion. Once crucial economic goals have been achieved, other goals gain in importance, and the reasons for staying at the mine are often a combination of these.

Even though employees commuting to Forrestania have rest periods of several days, the 


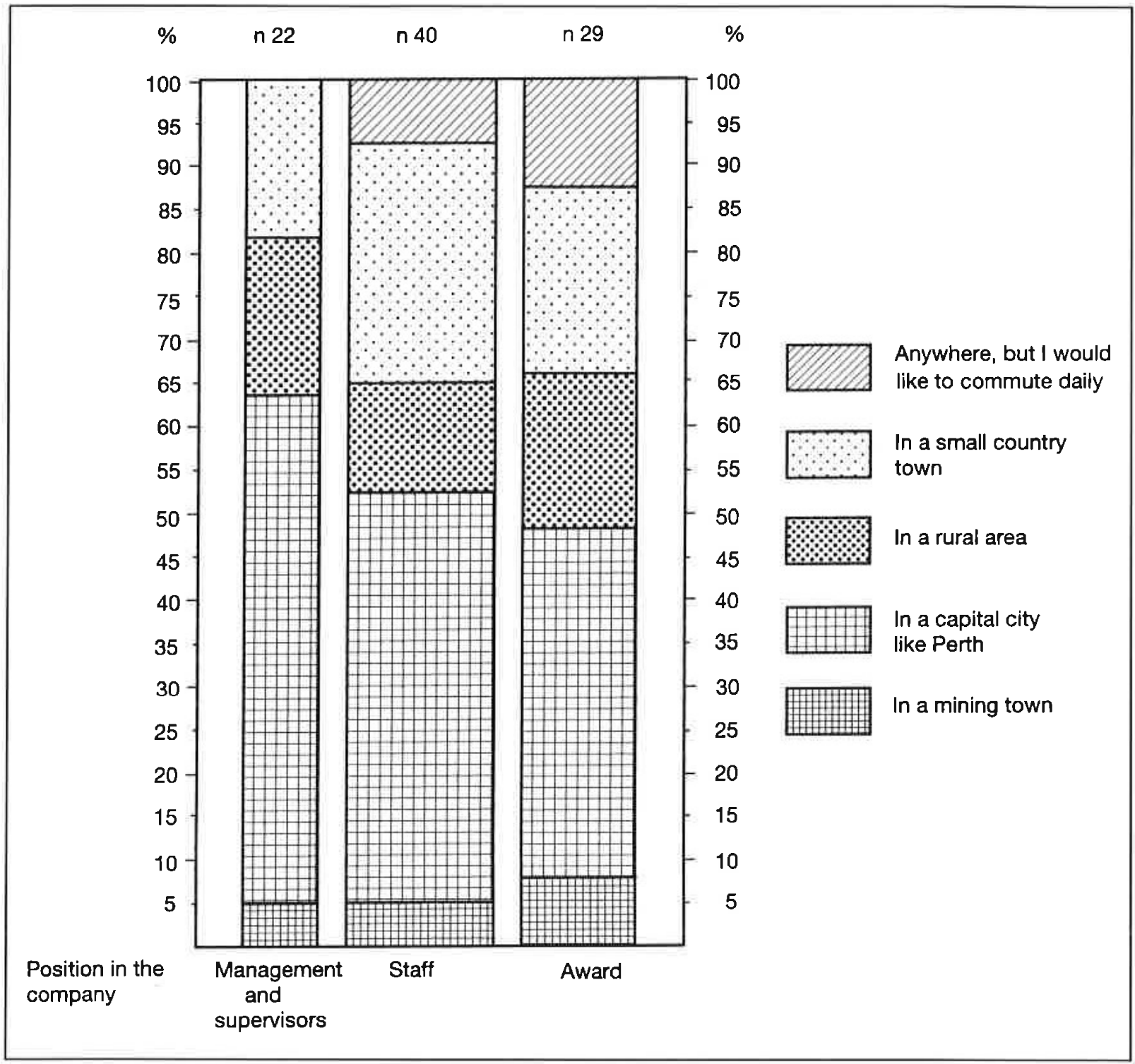

Fig. 5. Settlement types preferred by employees.

total time spent outside the home is much longer than with an ordinary work schedule. Thus it is not the length of the leisure time but the arrangement of it into periods that the employees themselves consider so important. Those employed in the administration of the Forrestania Mines work on weekdays and spend their weekends at home. All in all, the employees of Forrestania agreed emphatically with the statement that they like working on a rotational basis more than living and working in a mining town. The choice must be seen in context, of course, in that many of them have only two options: to work period- ically in the outback or to live there permanently.

\section{Housing preferences and attachment to a home environment}

When the employees in Forrestania were asked in which type of settlement they would most like to live at their present stage in life if they had a choice, and were given four options in addition to daily commuting, they preferred a metropolitan area, with a traditional mining town emerging as the least favoured option (Fig. 5). Country towns or rural 
areas were also feasible options for quite many. The distribution of opinions was slightly dependent on the social status of the employees, so that the higher their status was, the more they preferred the metropolitan option.

A metropolitan area was not greatly valued as a dwelling place among the employees living in the contractors' camp, many of whom themselves lived in a non-metropolitan environment and had no opportunities to commute by air, which may have caused this difference in opinion. They also more often preferred daily commuting. The obvious conclusion, as observed in many geographical studies, is that the employees prefer the settlement type in which they are currently living, and the housing arrangements made in conjunction with long-distance commuting do not constitute an exception. Comparing the results between the groups of employees, it is evident that employees adapt themselves to long-distance commuting and accommodation at the working site if commuting is well organised and the accommodation and housing satisfies their expectations.

Housing is a part of consumption, which can be interpreted in a broad sense as including enjoyment of a social life and environmental amenities. After the satisfaction of basic needs such as shelter and food, there are higher needs which people feel it important to satisfy and which become crucial in everyday life. A consumer selects an optimal combination of such consumption opportunities every day, and this combination varies by locality, which means that a move to a new locality entails the solving of a multidimensional problem, the choice of a way of life. The opinions of the employees of Forrestania on this were obtained by asking them to assess the strength of the factors which had influenced their decision to continue living in their current homes (Table 1).

It is a simple fact that the employees of Forrestania must live elsewhere and commute, because that is the way the mining company set things up, but it is interesting to see what sort of attachments the employees have to their home environment, and whether those attachments could be compensated for by money or by providing services if there were housing opportunities available in the surrounding towns and rural area. The employees are divided into two groups, those who live in Perth and those who live elsewhere.

The results indicate that the employees have a very strong attachment to their home environment (Table 1). Those living in Perth do not wish to abandon their metropolitan lifestyle, and this is the most important reason for their continuing to live there. The employees already living in a metropolitan environment enjoy a wide supply of commodities and recreational facilities. The quality of the natural environment within the metropolitan area was also ranked very high by the employees living in Perth, and social life was an important factor tying them to their present homes.

The lifestyle factor was also important for the employees who lived elsewhere, but it was the statement: "I enjoy the natural environment around our home town/region" that they ranked the highest, i.e. it was the natural environment that they appreciated most. The opportunities for bringing up children were the highest priority among those with a family, which indicates a changing pattern of needs when children are born.

The reason for preferring long-distance commuting from Perth instead of any other housing practice is obvious. The overwhelming majority of the employees commuting from Perth preferred to live in their home environment, and it seems that its services, lifestyle and social networks foster an attachment to their homes. The spouse's job opportunities and access to relatives are not important ties, and the employees do not consider their domicile especially appealing in the sense of the costs of housing and the workrelated factors. The company would thus have a difficult task ahead, if it wished to attract the employees to move to another locality, because they would have to be compensated for losses in the complex field of lifestyle and environment.

It has often been shown that people prefer the environment in which they are currently living, but it is something of a surprise that such factors as lifestyle and the prevailing environment were ranked above economic and employment factors to such marked extent. This emphasis held true both among those having their families in Perth and among those living elsewhere (Table 1). Both had similar profiles of answers, and the differences do not reveal any strong dissatisfaction with their home regions. The high scores 
Table 1. Reasons for employees at the Forrestania Nickel Mines in April 1993 continuing to live in their existing homes. 102 respondents; arithmetic mean for each statement. Scale 1 = a major consideration, $2=$ a minor consideration, $3=$ not a consideration .

\begin{tabular}{lcc}
\hline Statements & $\begin{array}{c}\text { Domicile in } \\
\text { Perth } \\
(\mathrm{n}=67)\end{array}$ & $\begin{array}{c}\text { Domicile } \\
\text { else where } \\
(\mathrm{n}=35)\end{array}$ \\
\hline I like the lifestyle in my home town/region & 1.4 & 1.7 \\
Our home town/region is pleasant to live in & 1.6 & 1.8 \\
I like the climate & 1.6 & 1.9 \\
I enjoy the natural environment around our home town/ region & 1.7 & 1.6 \\
I have good friends there & 1.7 & 1.9 \\
The high quality of our permanent accommodation & 1.7 & 1.8 \\
Our home town/region is a fine place to bring up children & 1.8 & 1.8 \\
$\quad$ (all respondents) & 1.3 & 1.5 \\
Employees who have children: Our home town/region is a & 1.8 & 1.8 \\
$\quad$ fine place to bring up children & 2.2 & 1.9 \\
I still find new experiences there & 2.2 & 2.1 \\
My present job keeps me there & 2.3 & 2.3 \\
I am much better off financially there than if I left & 2.3 & 2.4 \\
The low cost of housing keeps me there & & 2.8 \\
My spouse or I have close relatives there & 2.5 & 2.8 \\
My spouse couldn't get a job with as much responsibility and/ & 2.8 & \\
$\quad$ or chance of advancement anywhere else & & \\
\hline
\end{tabular}

attached to the urban lifestyle and environment statements given by the employees living in Perth indicate that the metropolitan environment is well appreciated and there are no weighty grounds to change the commuting practice on the grounds of the residential environment.

It is important to recognise that these crucial needs are not basic, tangible ones, and thus cannot easily be compensated for with money. The higher the income, the more difficult it is to find such forms of compensation.

The variety of home environments possessed by the Forrestania employees cannot be provided in small communities in remote areas. Even though many would prefer a nonmetropolitan environment, mining towns are not ranked high (Fig. 5). Thus a rural mining locality is not generally attractive as a permanent settlement even among those who dislike metropolitan lifestyles, and it is not a viable option for housing.

The lifestyle factor attaches the employees to their homes, and these emotional and social ties constitute very important reasons for staying there and cannot easily be replaced or compensated for by abundant fringe benefits or supplementary investments in a company town. As experiences in mining towns indicate, a company house - even when better than a house in a suburb - does not guarantee employee satisfaction (Brealey 1988). One's lifestyle, social relations and home atmosphere are not transferable to other localities or compensated for by better housing. The preference for the long-distance commuting option is firmly anchored in the employees' experiences of everyday life, when once it has been established.

\section{Flexibility of human resource policy}

Long-distance commuting is a substitute for living permanently in an undesirable locality, and many employees prefer commuting and compressed work schedules for that reason. This inquiry showed that people are still attracted to work in the outback by economic 
factors, but it can be predicted that as production processes come to demand more and more qualified employees and as companies become willing to pay higher salaries and wages, economic factors will lose their appeal and attachment to the home environment will gain in strength. The human resource policy of each company using long-distance commuting must hence continuously find a balance between different motivating factors.

The image of fly-in/fly-out mining operations in Australia is a positive one, and this is certainly conducive to acceptance of the practice. The employees emphatically agreed with the statement that working on a rotational basis and living in accommodation complexes is an advanced way of organising work at a mine. Similar impressions were perceived in Zaldivar, Chile, in 1995. Therefore, rotational work and commuting are linked to a new type of work culture which incorporates the use of advanced technology in work and commuting, and a very individual lifestyle far from a work environment. The consideration of lifestyle preferences in work and free time is hence an integral part of human resource policy for a company.

The employees of the Forrestania Nickel Mines did not generally disagree with the statement that the rotational work schedule causes problems for family life. In fact, they did not have any strong opinions one way or another. On the other hand, they reluctantly agreed that the resulting family problems can be overcome without serious difficulties or drawbacks. Thus, the effects on family life are mainly detrimental but can be overcome to some extent. The majority of the employees were married, and $37 \%$ of them had children. Thus, the compatibility of the working schedule with family life is crucial for the future of the rotational work schedule.

A few work schedules at Forrestania had been tailored according to individual needs, as some employees preferred long rotations. Although there was no general desire to have more flexible working hours, work schedules should be looked on as alternatives which can be tailored to personal preferences when this is technically and economically appropriate. Some subcontractors maintained very long rotations in Forrestania, which may not be problematic for a married couple on-site, for instance, but could be unsuitable for an employee who has a family in the metropolitan area. All in all, a certain flexibility, careful design and the ability to anticipate different needs seem to be paying off in human resource policy.

\section{An explanation for the development of the settlement pattern}

The entire settlement pattern and spatial structure of outlying tracts can be changed by the development of new, highly-automated industrial production methods, and many good reasons emerged in this inquiry to explain the diffusion of long-distance commuting to such areas. These included technical improvements, the necessity for economic activities in remote areas, economic considerations for the company, employees' economic motives and individual choices, and emotional and social attachments. Long-distance commuting with a compressed work schedule is the outcome of a combination of reasons all operating at the same time. This development process is interpreted in a more general form as the emergence of a new spatial and settlement structure (Fig, 6). The technical and economical reasons spoken of here for the diffusion of new spatial structures are controlled mainly by the business enterprises, the search for high pay, a personal lifestyle and a pleasant home environment are evaluated by the individuals, i.e. employees and their families, and the institutional conditions are set by the authorities (Fig. 6). In order for a new practice to be implemented, each of these instances must accept it.

A company will naturally search for cheaper ways of arranging housing and flexibility in the use of labour, and will aim to avoid industrial action and social problems. From its point of view, new spatial structures can be implemented provided that the new working and commuting arrangements associated with them are economically feasible for the company.

Individuals, in turn, seek to maximise their welfare. As the Forrestania case shows, the employees are searching for opportunities to adopt an advanced lifestyle and take advantage of a wide range of consumer facilities. Their preferences reflect a lifestyle originating from their home environment. Hence new spatial organisations are developing in the direction which provides significant opportunities for employees to retain their lifestyles. 


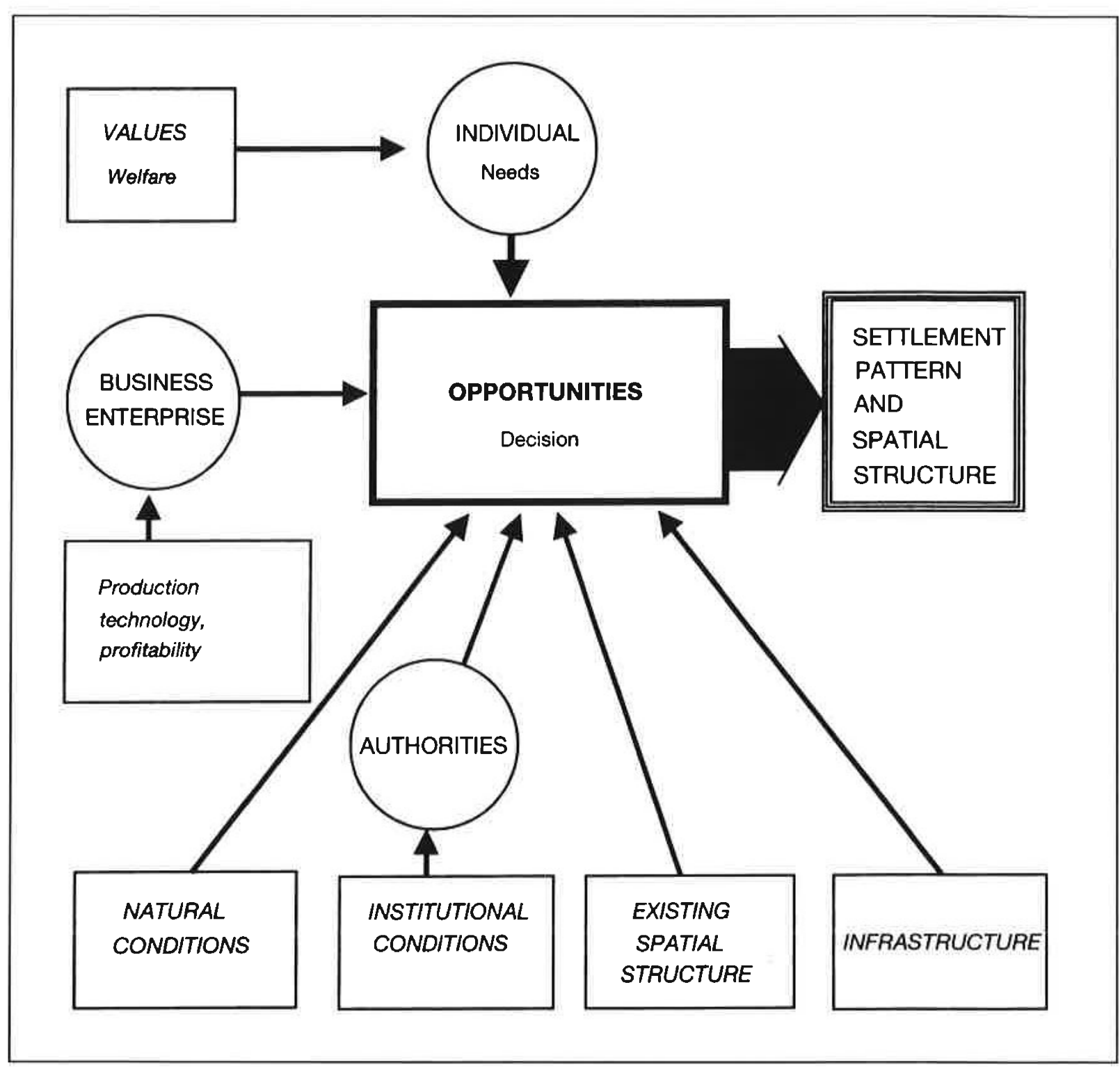

Fig. 6. Factors influencing settlement pattern and spatial structure.

It is the authorities that create the institutional conditions necessary for the evolution of the spatial structure, and it is they who are searching for fiscal benefits on a local scale. In the case of the mining sector, small mining towns have proved expensive to maintain and long-distance commuting is preferred by authorities as a cheaper alternative in Australia (Anon. 1996). Increased long-distance commuting and commuter mining have been considered economic and acceptable by the Chilean authorities, as also by the regional authorities interviewed by the author in Antofagasta in autumn 1995.
The negligible local employment and income impacts of long-distance commuting have been criticised, but they are very hypothetical even in the case of a potential company town, because entire industries are changing from locally operating production units to units which require a global operating environment (Tykkyläinen 1996). Nevertheless, an irrational move from a social point of view seems to be the plan to close some existing mining towns in Australia, where the companies intend to use long-distance commuting instead of recruiting locally (Houghton 1993: 287). These excesses are rare, however. 
Advanced commuting does not entail any inevitable tendency for spatial concentration, but it can lead to very flexible spatial arrangements. In some cases commuting opportunities can be offered to employees from smaller agglomerations, as has been done in Canada. The pattern of long-distance commuting in Canada is spatially more dispersed than in Australia, the employees often being picked up from several cities, towns and villages (Storey \& Shrimpton 1994: 100-101). This allows the income and employment effects of resource processing to be spread over several localities. Hence long-distance commuting may lead to a spatially dispersed pattern of recruitment and permit employees to live in the communities of their choice.

New settlement and spatial structures can also be looked on as an easier means to the end of satisfying the demand for labour than traditional ones. Furthermore, when individuals prefer these new arrangements, there is no longer much room for other options.

\section{A fragmented spatial structure and pockets of development}

Geographers have long been fascinated by the patterns and evolution of human settlements. What forms does the spatial structure take? Are these forms random or regular? Do differences exist by region, and why? When novel commuting practices are diffusing, a crucial issue is what roles new developments such as long-distance commuting play in the spatial structure.

The experiences gained from the Forrestania inquiry may be depicted in the form of a simulation model, which helps to illustrate the basic pattern of the new spatial structure brought about by long-distance commuting. The workforce is habitually fragmented, as Houghton (1993: 283) put it in his analysis of the spatial consequences of long-distance commuting. The fragmented spatial structure consists of a combination of resource communities, often temporary and randomly distributed ones, connected with pick-up points for employees commuting over the intervening distances. This randomness is nevertheless a symptom of the fact that the friction of distance does not create the forms of spatial structure that it is assumed to create in traditional central place models. The decisions, as depicted in Fig. 6, are made in a geographical space which is experienced on time and distance scales created by advanced communications technology. The principles of the formation of spatial structures are not so much based on roads and railways as on networks and flights as the bases for the new information economy (Castells 1993: 20). Under these conditions, the traditional central place model does not fit such a pattern of interaction, commuting and settlement.

The inappropriateness of the traditional approach and its spatial manifestations arises for several reasons. Firstly, in rural areas, where the distribution of natural resources and the economic quality of the land will vary, the spatial pattern follows conditions dictated by the physical environment (Brunn \& Ziegler 1981). Secondly, air connections make commuting independent of traditional scales of distance. The longest regular mass commuting flights in Western Australia are $2,200 \mathrm{~km}$, but elsewhere there are individuals who commute from Venezuela and the UK to Canada (Storey \& Shrimpton 1991: 26). Thirdly, commuting takes place from pointto-point, according to the network of airports. Fourthly, employees live in both localities and their spatial behaviour is thus bifurcated. Fifthly, the hierarchical market area approach to acquiring commodities and as a central rule in shaping the settlement structure is irrelevant under these bifurcated conditions.

The virtual pattern of this fragmented spatial structure (Fig. 7) is constructed on the observation that the traditional regularity of settlement structure and the gravitational analogy as a representation of spatial interaction are not valid any more. The principles of the model developed here, which produced the pattern (Fig. 7), are based on the abovementioned spatial characteristics of commuter mining.

Spatial interaction consists of commuting and other travel on the scale of the area depicted (Fig. 7). The circles depict the size of the centres in terms of population, and the thicknesses of the lines represent the volume of spatial interaction. The assumptions of the model are as follows:

1. There are $n$ circles, i.e. a metropolitan area and $n-1$ other centres.

2. The largest circle depicts the metropolitan area, and is randomly located. Its size represents a rough approximation of the popu- 


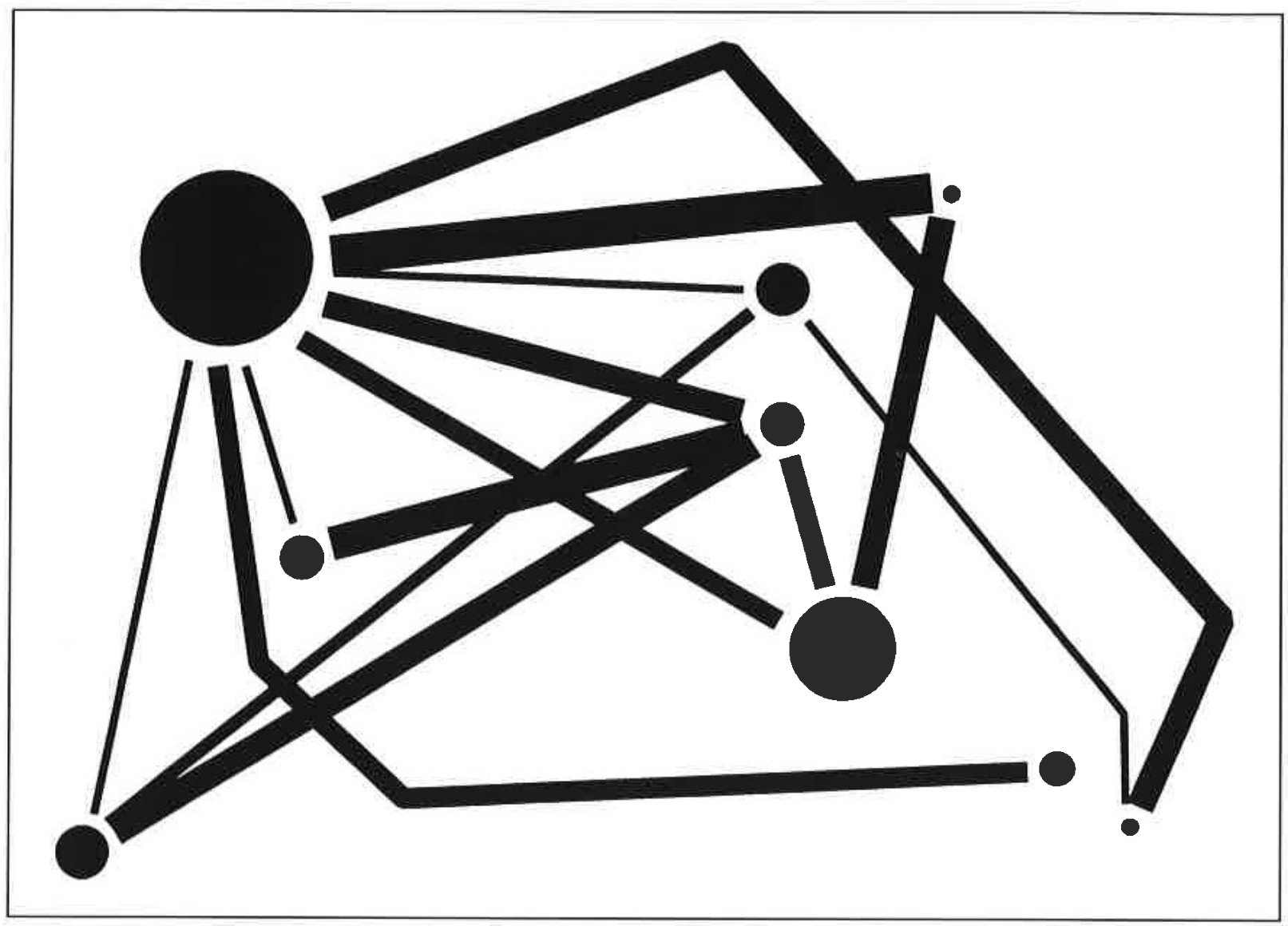

Fig. 7. A fragmented spatial structure. The circles depict centres and the flows between them the spatial interaction.

lation of a metropolitan area in relation to the towns in the outback.

3. The size of each centre is selected at random and scaled by the rank-size rule.

4. The centres are distributed randomly.

5. The spatial interaction is a set of $n+m$ links departing from the centres and proceeding to other centres. The set of $\mathrm{n}$ random links is supplemented by $\mathrm{m}$ additional links with fixed departure from the metropolitan area and proceeding to those centres which would otherwise have no link with the metropolitan area.

6. The volume of spatial interaction is random.

The above set of rules can be seen as the elements of a model which can be run on a calculator or computer. The model results in different imaginary regional patterns, one of which has been selected for the figure
(Fig. 7). This represents a generalisation of the settlement system of Western Australia that has developed due to the implementation of long-distance commuting in the mining industry. It is also comparable to the development of Region II in Northern Chile, where commuter mining is diffusing rapidly. The simulation actually depicts the randomness of the distribution of natural resources, or favourable localities for production, which can be exploited in spite of distance and often provide a restricted environment for living. Some of the nodes are naturally residential settlements.

A flow of goods, people and information exists between localities, and the degree of this spatial interaction varies quite irregularly within the whole area (Fig. 7). The commuting pattern may also be a mixture of daily and long-distance commuting by bus, car and aircraft. Contracting creates temporary inter- 
actions between the pick-up points and the mining areas.

As experiences in Australia and some other countries show, mining companies are ready to maintain and develop long-distance commuting, and employees prefer this to living in a mining town. Thus fragmented structures of this kind are likely to become more common in the near future.

The fragmentation spoken of here can be seen in the broader context of regional development in general. One notion to emerge from this investigation is the discrete nature of modernisation. Any division of countries into developed and developing, or on a global scale into a developed block in the north and an underdeveloped block in the south, is apt to be too rough. Furthermore, the diffusion of recent technological applications and advanced business follows a pointwise pattern rather than being a smooth process advancing from the source of innovation to the periphery.

Development is taking place more and more at nodes in the global network of competitive locations. As has been seen in mining, this is due to the abolishing of trade barriers on a world scale, improved communications and the expanding transnational business culture. Economic growth and development tend to take place in favourable pockets, localities which are able to attract investments on a worldwide basis (Tykkyläinen 1995).

This metaphor of favourable pockets seems to be valid for recent industrial developments in many countries, especially in the sectors producing raw materials, bulk products and energy. Long-distance commuting must be interpreted as an inherent factor in the development of settlement and infrastructure patterns in this age of globalised business.

\section{Conclusions}

\section{Causes and effects}

The prerequisites for long-distance commuting have resulted from technical and economic developments which make this arrangement the most economic option for a company wishing to organise work in remote resource sites hundreds of kilometres away from urban areas. Long-distance commuting and similar commuting arrangements have become viable options among the employees because this means that they are still able to enjoy urban amenities and the life of their home environment.

Commuting with accommodation on-site is expanding in marginal areas and has proved to be feasible in many countries for economic, technical and behavioural reasons. Such developments could be controlled by introducing restrictive taxes or regulations, of course, but this has not been done in Western Australia or Chile up to the mid-1990s, at least.

Physical distance is not such a barrier within long-distance commuting as in ordinary commuting, and the spatial interaction is almost a random function of distance. When long-distance commuting becomes frequent in a region, the settlement pattern becomes a combination of resource communities, often unpredictably distributed but connected with the necessary pick-up points, which also calls for new administrative practices. Local authorities in their current spatial forms, such as shires or cities, do not necessarily satisfy the needs of commuting employees as well as they do the needs of non-commuting residents. Local administrative practices should be commensurate with the new spatial behaviour.

The model of a fragmented spatial structure condenses the newly arising spatial structure into a few basic concepts and processes. The settlement pattern and spatial interaction previously depicted by the urban-rural hierarchy, spheres of influence and the gravitational analogy are now more random, and the settlements gain a network character imposed by the mining industry, and probably many other resource-based sectors as well. It is anticipated that long-distance commuting will become an integral and more frequent part of spatial interaction in remote settings.

\section{Prospects}

The concept of commuting combined with the provision of an accommodation complex of a high standard at the production site is an innovation in terms of town and regional planning, and its diffusion is expected to continue. A good proportion of the surface of the earth is sparsely populated and capable of receiving such communities. From the European standpoint, the shore of the Barents Sea and outlying places in Siberia could be areas in which long-distance commuting would be 
applicable. This concept has not been applied in the north of Russia on a large scale, although some companies have used aircraft to fly employees over the Pole from Canada to northern Russia (Euroflite 1994). The more conventional practice of commuting, i.e. use of an accommodation complex in combination with commuting by bus, applies best to inhabited environments, and a compressed work schedule with on-site accommodation and commuting by car has been planned for areas such as northern Scandinavia, which are more densely populated.

Long-distance commuting is also feasible in developing countries. A technologically advanced industry such as high-tech mining does not need large amounts of unskilled labour, but instead its production technology calls for a few highly skilled employees. Technology cannot be replaced by cheap labour. Thus, novel commuting and settlement arrangements, as described in this paper, can apply to societies of various kinds, and not only in the developed countries. Chile, where accommodation complexes at mining sites do not differ from the Australian ones in quality, is a good example of the globalisation of this commuting-based settlement innovation and its spread to a developing country.

Spatial structures are developing alongside advanced transport and communications technology. Development takes place in suitable pockets rather than diffusing smoothly towards a periphery. As the countries of the world become increasingly integrated in the economic sense, local development will be more and more dependent on the competitiveness of single "globally selected" places and their communications links on an international scale. Potential investors are scanning the suitability of localities in order to seek to complement their production network. Local development and spatial structures are outcomes of this economic networking and integration on the global level. "Camps in deserts" and flying miners are only one symptom of this new restructuring in our geographical space.

\section{ACKNOWLEDGEMENTS}

This research was partially funded by the University of Joensuu, the Academy of Finland and UNU/WIDER, under its Special Finnish Project Fund, which is supported by the Finnish Ministry for Foreign Affairs.

\section{REFERENCES}

Anon. (1996). Fly-in commuting upsets locals. Australian Mining, Jan./Feb. 1996, 8-10.

Batten, David F. (1993). Network cities versus central place cities: building a cosmo-creative constellation. In Andersson, А. E., D. F. Batten, K. Kobayashi \& K. Yoshikawa (eds.). The cosmocreative society, 137-150. Springer-Verlag, Heidelberg.

Brealey, Terry (1988). The social outcome of the design of the built environment in remote settings: a vignette of CSIRO remote communities environment unit research. In Brealey, T., C. C. Neil \& P. W. Newton (eds.). Resource communities, settlement and workforce issues, 145149. CSIRO, Melbourne.

Brotchie, John (1991). Fast rail networks and socioeconomic impacts. In Brotchie, John, Michael Batty, Peter Hall \& Peter Newton (eds.): cities of the 21st century, 25-37. Longman, Melbourne.

Brunn, Stanley D. \& Donald J. Ziegler (1981). Human settlements in sparsely populated areas: a conceptual overview, with special reference to the U.S. In Lonsdale, Richard E. \& John H. Holmes (eds.). Settlement systems in sparsely populated regions, 14-52. Pergamon, New York.

Castells, Manuel (1993). The informational economy and the new international division of labour. In Carnoy, Martin, Stephen S. Cohen \& Ferdinando Henrique Cardoso (eds.). The nezv global economy in the information age, 15-43. Pennsylvania State University Press, University Park, PA.

Conti, Sergio (1993). The network perspective in industrial geography: towards a model. Geografiska Annaler 75 B, 115-130.

Dicken, Peter (1990). Transnational corporations and the spatial organization of production: some theoretical and empirical issues. In Shachar, Arie \& Sture Öberg (eds.). The world economy and the spatial organization of power, 31-55. Avebury, Aldershot.

Euroflite (1994). Telephone interview with the manager. September 1994. Helsinki.

Freeman, Christopher \& Carlota Perez (1988). Structural crises of adjustment: business cycles and investment behaviour. In Dosi, Giovanni, Christopher Freeman, Richard Nelson, Gerald Silverberg \& Luc Soete (eds.). Technical change and economic theory, 38-66. Pinter, London.

Holmes, John H. (1981). Lands of distant promise. In Lonsdale, Richard E. \& John H. Holmes (eds.). Settlement systems in sparsely populated regions, 1-13. Pergamon, New York.

Houghton, D. S. (1993). Long-distance commuting: a new approach to mining in Australia. The Geographical Journal 159, 281-290.

Humphreys, David (1995). Whatever happened to security of supply? Minerals policy in the postCold War world. Resources Policy 21, 91-97. 
ISY (1985), (1988). Industrial statistics yearbook 1982, 1986. United Nations, New York.

Luostarinen, Reijo (1994). Internationalization of Finnish firms and their response to global challenges. 52 pp. Research for Action, UNU/WIDER, Helsinki.

Newton, Peter \& Ira Robinson (1987). Settlement options: avoiding local government with fly-in fly-out. In Parker, Paul (ed.): Developments in local government, 5. resource development and local gooernment: policies for growth, decline and diversity, 72-81. AGPS, Canberra.

Outokumpu (1996a). Outokumpu anmual report 1995. Outokumpu, Espoo, 78 pp.

Outokumpu (1996b). Outokumpu, osavnosikatsaus 1.1.-31.8.1996. Outokumpu, Espoo, 8 pp.

Parkers, D. N. \& N. J. Thrift (1980). Times, spaces, and places, a chronogeographic perspective. $527 \mathrm{pp}$. John Wiley and Sons, Chichester.

Persson, Lars Olof \& Ulf Wiberg (1995). Microregional fragmentation, contrasts between a welfare state and a market economy. $132 \mathrm{pp}$. Physica-Verlag, Heidelberg.

Pukkila, Jukka, Risto Kuivanen, Kaarin Ruuhilehto \& Raimo Matikainen (1994). Älykäs kaivos teknologiahanke. TKK-KAL A12. 47 pp.

Storey, Keith \& Mark Shrimpton (1991). Long-distance commuting, mining and hydrocarbon industry management issues. Paper presented at the Australian Mines and Metals Association
Conference "Long-Distance Commuting in the Mining and Hydrocarbon Industries", Glenelg, South Australia, June 19-20, 1991. 41 pp.

Storey, Keith \& Mark Shrimpton (1994). From new town to no town, implications of the increasing use of commuting by the Canadian mining industry. In Andrey, J. \& G. Nelson (eds.). Public issues, a geographical perspective, 88-110. Publication Series Number 41, Department of Geography, University of Waterloo.

Tykkyläinen, Markku (1994). Kaupunkilaismainarit Forrestaniassa - työpaikkamajoituksen vaikutus aluerakenteeseen Länsi-Australiassa. 214 pp. Joensuu University Press, Joensuu.

Tykkyläinen, Markku (1995). "Stunde Null" and the pocket theory of development in the socioeconomic transition in Russia; Introduction to the Course. In Tykkyläinen, Markku (ed.). Russian Karelia - an opportunity for the west, 9-21. Occasional Papers 29, Human Geography and Planning, University of Joensuu.

Tykkyläinen, Markku (1997). Abandoning the traditional community model, a mine in Western Australia. In Neil, Cecily \& Markku Tykkyläinen (eds.). Resource communities - a search for stability in the 1990s (in press).

Urry, John (1990), Conclusions: places and policies, In Harlow, Michael, C. G. Pickvance \& John Urry (eds.). Place, policy and politics, do localities matter? 187-204. Unwin Hyman, London. 